\title{
PSYCHOLOGY IN AFRICA
}

\section{A BIBLIOGRAPHICAL SURVEY}
H.C. MARAIS
J.C. HOORWEG

\author{
University of Port Elizabeth, Rampala, Ouganda \\ Makerere University, Kampala, Ouganda
}

Several methods of surveying a social science in a particular country or continent are conceivable. A professional approach could be used, consisting of an analysis of the opportunities for both tesearch and training is a specific geographical area, supplemented with a description of the professional societies. An example of this approach is Ardila's (I968) description of psychology in South America. A second, personnel oriented method could consist of a systematic analysis of the activities of indigenous psychologists, complemented with a list of professional societies and visiting psychologists from abroad. Van Bergen and Jaspars (I968) used this approach in their teview of social psychology in the Netherlands.

A third alternative was followed in the present study, a bibliograpbical approach, i.e., a descriptive analysis of publications in terms of a number of categories. Although until recently there were few indigenous psychologists or training facilities, a considerable amount of psychological research has been done in Africa, so that a bibliographical study of publications pertaining to African populations could be elucidating.

This paper presents an analysis of the titles in a recent bibliography on psychology in Africa (Hoorweg and Marais, 1969). In this bibliography, publications were included irrespective of quality, but confidential teports or papers pertaining to white subjects only were omitted. The I 3 I 2 entries were categorized in terms of (a) year of publication; (b) field of psychology using the classification of the $P_{s y}$ cbological Abstracts, 1 (c) geogtaphical location, i.e., that part of Africa with which the paper dealt; (d) language of publication; and (e) publication medium, e.g., journals, books, etc. Cross-tables were extracted from these data. In the presen-

\footnotetext{
I In the compilation of the bibliography, the authors classified, independently of each other, each reference into the main categoties. These judgments corresponded in $95 \%$ of the cases. The remaining $5 \%$ were classified after discussion. The classifications into subdivisions were done jointly.
}

INTERNATIONAL JOURNAL OF PSYCHOLOGY

JOURNAL INTERNATIONAL DE PSYCHOLOGIE - VOL $6, \mathrm{~N}^{\circ} 4$ 
tation below, the totals for each category are presented first, while in the second part some cross-tables are discussed.

\section{Year of publication}

\section{RESULTS IN EACH CATEGORY}

The number of publications per decade is presented in Table I. It can be seen that since the emergence of psychology as a modern science at the end of the rgth century, there has been a continuous increase in papers over decennia

TABLE 1

NUMBER OF PUBLICATIONS PER LANGUAGE AND OVER DECADES

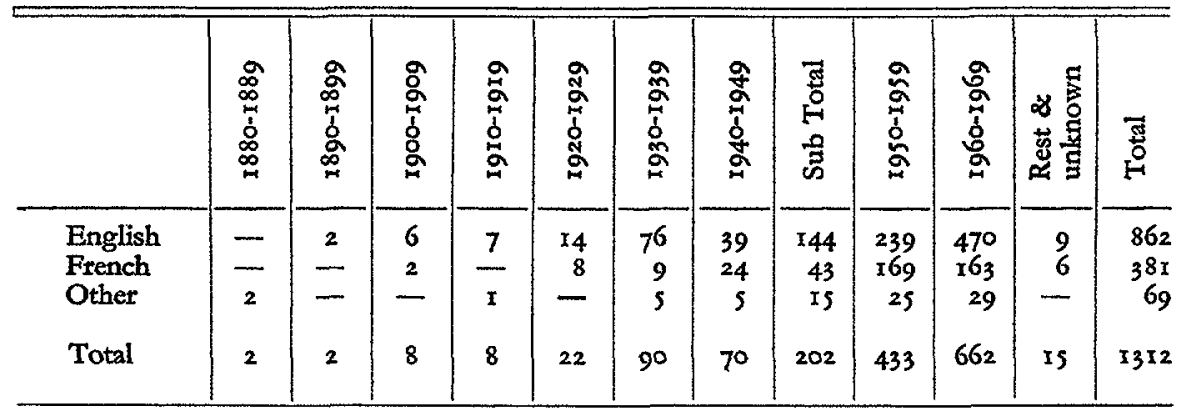

(except for the period 1940-1949), with a rapid expansion since r950. A breakdown in four-year periods since 1950 shows the following totals : 99, 179, 284, 279 and 254 for the last period of $1966-1969$. The greatest increase apparently occurred from 1954 to $196 \mathrm{I}$, with a more even development since $x_{962}{ }^{2}$.

\section{Language of publication}

Table I shows that the total of $x_{3} 12$ compiled titles, $862(65.7 \%)$ were in English, 381 (29\%) in French, and $69(5.3 \%)$ in German, Afrikaan, Dutch and other languages.

\section{Field of psychology}

Table 2 shows both the totals and the important subdivisions for each separate field of psychology. The field of personality headed the list in number of publications, followed by social psychology, clinical psychology and personnel psychology. These four fields accounted for $63.1 \%$ of all publications.

There was a heavy emphasis on what might be called testing aptitudes and abilities. Four subdivisions concemed with this topic, i.e., tests (methodology), aptitudes and abilities (personality), testing (educational), and selection and

2 The bibliography was closed in June 1969 ; the period $1966-69$ thus barely covers three and a half years.

INTERNATIONAL JOURNAL OF PSYCFOLOGX - JOURNAL INTERNATIONAL DE PSTCHOLOGIE 
placement (personnel) together constituted more than $20 \%$ of all publications.

"Aptitudes and abilities" also stood out as the most prominent area in the field of personality psychology. Few studies were concerned with other aspects

TABLE 2

DISTRLBUTYON OF PUBLICATTONS OVER FIELDS OF PSYCHOLOGX

\begin{tabular}{|c|c|c|c|}
\hline Field & $\mathbf{N}$ & Subcategory & $\mathbf{N}$ \\
\hline Genetal & $(5.3 \%)$ & $\begin{array}{l}\text { Psychology of the African or specific African } \\
\text { gtoup } \\
\text { Bibliographies \& reviews } \\
\text { Others combined }\end{array}$ & $\begin{array}{l}22 \\
22 \\
26\end{array}$ \\
\hline Methodology & $(5.7 \%)$ & $\begin{array}{l}\text { Tests } \\
\text { Others combined }\end{array}$ & $\begin{array}{l}49 \\
26\end{array}$ \\
\hline Experimental & $(6.8 \%)$ & $\begin{array}{l}\text { Pexception } \\
\text { Vision } \\
\text { Others combined }\end{array}$ & $\begin{array}{l}27 \\
29 \\
33\end{array}$ \\
\hline Physiological & $\begin{array}{c}25 \\
(x .9 \%)\end{array}$ & $\begin{array}{l}\text { Neurology \& electroencephalography } \\
\text { Others combined }\end{array}$ & $\begin{array}{r}16 \\
9\end{array}$ \\
\hline Developmental & $\begin{array}{c}123 \\
(9.4 \%)\end{array}$ & $\begin{array}{l}\text { Infancy } \\
\text { Childhood } \\
\text { Others combined }\end{array}$ & $\begin{array}{l}15 \\
90 \\
18\end{array}$ \\
\hline Social & $\begin{array}{c}23 \mathrm{I} \\
(\mathrm{x} 7.6 \%)\end{array}$ & $\begin{array}{l}\text { Culture \& social processes } \\
\text { Attitude and opinion } \\
\text { Group and interpersonal processes } \\
\text { Others combined }\end{array}$ & $\begin{array}{l}80 \\
65 \\
47 \\
39\end{array}$ \\
\hline Personality & $\begin{array}{l}236 \\
(18 \%)\end{array}$ & $\begin{array}{l}\text { Aptitudes \& abilities } \\
\text { Personality measurement } \\
\text { Psychoanalysis } \\
\text { Others combined }\end{array}$ & $\begin{array}{r}149 \\
29 \\
18 \\
40\end{array}$ \\
\hline Clinical & $(x 5.8 \%)$ & $\begin{array}{l}\text { Therapy \& analysis } \\
\text { Psychosis } \\
\text { Behaviour disorder } \\
\text { Neurosis \& emotional disturbance } \\
\text { Others combined }\end{array}$ & $\begin{array}{l}40 \\
35 \\
26 \\
16 \\
90\end{array}$ \\
\hline Educational & $\begin{array}{c}102 \\
(7.8 \%)\end{array}$ & $\begin{array}{l}\text { Testing } \\
\text { School leatning, teaching method \& special } \\
\text { education } \\
\text { Others combined }\end{array}$ & $\begin{array}{l}30 \\
23 \\
49\end{array}$ \\
\hline Personnel & $\begin{array}{c}I 54 \\
(\mathrm{x} \times 7 \%)\end{array}$ & $\begin{array}{l}\text { Selection \& placement } \\
\text { Performance \& job satisfaction } \\
\text { Othets combined }\end{array}$ & $\begin{array}{l}65 \\
24 \\
65\end{array}$ \\
\hline Total & 1312 & & $13 \sqrt{12}$ \\
\hline
\end{tabular}

of personality, even if one allows for the fact that studies relating to child rearing and personality were classified under developmental psychology.

VOL. $6, \mathrm{~N}^{0} 4$ 
Social psychology provides links with the other social sciences as is reflected in the relatively large number of studies on culture and social processes. Clinical psycholog $y$ has mostly been concerned with the classification and description of mental illnesses, therapy and analysis, and paid moderate attention to behaviour disorders. Personnel psycholog $y$ consisted largely of studies on selection and placement, and on performance and job satisfaction. In experimental psycbology, the emphasis on studies of perception and vision is striking.

\section{Geographical location}

The number of publications which each geographical area has contributed towards the total was as follows : $42(3.2 \%)$ from North Africa, $798(60.8 \%)$ from sub-Saharan Africa (i.e., excluding South Africa), and 243 ( $18.5 \%$ ) from South Africa; 135 (10.3\%) dealt with Africa and Africans in general. Ninety four studies $(7.2 \%)$ were unclassifiable, mainly because these studies were not at the compilers' disposal. (See 'Table 4, p. 334).

\section{Publication medium}

Most papers, more specifically $889(67.7 \%)$, wete published in journals, while 227 (I7.3\%) were book references, II 7 conference reports (8.9\%), $56(4.2 \%)$ theses, and $23(1.9 \%)$ unpublished papers. The 889 journal teferences were distributed over no less than 254 journals. Of these 254 periodicals only 40 contributed more than five articles ${ }^{3}$. These 40 journals among themselves produced a total of 495 titles. Consequently, the other 393 references were scattered over 214 periodicals, which ranged from sociological and anthropological publications through medical and psychiatric journals, to educational journals, and journals concerned with work and labour. This diffusion may well have hampered the development of psychology in Africa. Many of the journals ate relatively unknown, difficult to obtain, hav'e low circulation figures, and are, on face value, unlikely places to look for psychological papers.

\section{CROSS-TABLES}

\section{Year of publication $\times$ Field of psycbolog $y$}

The number of publications per field of psychology set out against decade of publication can be found in Table 3 (p. 333 ).

For each decade from 1880 to 1959 the section on personality contributed the largest number of studies. This singulatly prominent position is, however, almost entirely due to publications on aptitudes and abilities. The concentration on aptitudes and abilities probably reflected a general preoccupation of psychologists everywhere at that time. However, not everywhere did this preoccupation last until I96I, as it did in Africa. This may well have contributed to the relative isolation of psychology among the social sciences concerned with Africa. Only in recent years have departments of psychology been established at a number

3 Six journals produced more than 20 references each : Journal of Social Psychology; Journal NIPR = Psycbologia Africana; Psycbopatbologie Africaine; Africa; Bulletits CEPSI ; International Journal of Psycbology. 
of African universities, and interestingly enough, this also coincided with a shift of research interests after $196 \mathrm{r}$.

During the past decade social psychology has become the most productive area, followed by clinical psychology, while personality psychology has been relegated to a third position with the number of publications in this field steadily declining. The rise of social psychology is mainly due to a greater interest in the areas of attitudes and opinions and group and inter-personal processes. Also striking is the change in the rank of educational psychology - from eighth position in 1950-1959 to fourth position in 1960-1969.

TABLE 3

NUMBER OF PUBLICATIONS PER FIELD OF PSYCHOLOGY FOR VARIOUS PERIODS

\begin{tabular}{|c|c|c|c|c|c|c|c|c|}
\hline Field & 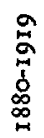 & 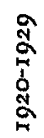 & 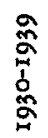 & 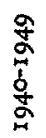 & 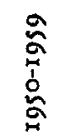 & $\begin{array}{l}\stackrel{g}{\circ} \\
\stackrel{2}{8} \\
\stackrel{8}{g}\end{array}$ & 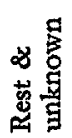 & 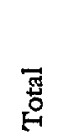 \\
\hline General & $x$ & 2 & 4 & 8 & 27 & 27 & $\mathbf{I}$ & 70 \\
\hline Methodology & I & - & $\begin{array}{l}4 \\
6\end{array}$ & 4 & 25 & 38 & I & 75 \\
\hline Experimental & 4 & - & 7 & I & I8 & 58 & I & 89 \\
\hline Physiological & - & - & 5 & I & I2 & 6 & $\mathbf{I}$ & 25 \\
\hline Developmental & 6 & 2 & 8 & 5 & 40 & 60 & 2 & 123 \\
\hline Social & I & $\bar{I}$ & 6 & 9 & 49 & $I 6_{3}$ & 2 & $23 I$ \\
\hline Personality & 3 & 12 & 33 & 16 & 93 & 78 & $\mathbf{x}$ & 236 \\
\hline Clinical & $\mathbf{I}$ & $I$ & 8 & 15 & $7 \pi$ & I IO & $\mathbf{I}$ & 207 \\
\hline Educational & 3 & 3 & 9 & 3 & 19 & 62 & 3 & 102 \\
\hline Personnel & $\underline{2}$ & $\mathrm{Y}$ & 4 & 8 & 79 & 60 & 2 & IS4 \\
\hline Total & 20 & 22 & 90 & 70 & 433 & 662 & Is & I 3 I 2 \\
\hline
\end{tabular}

Even more striking was the increase in studies in the field of experimental psychology since I966. As a matter of fact, for the least four years covered by the bibliography, studies in experimental psychology have taken second place, being exceeded only by studies in social psychology.

The overriding interest in aptitudes and abilities has lessened. Psychologists have become more concerned with experimental research into basic psychological processes, and with social psychology and its complex social problems, a meeting point with the other social sciences.

\section{Year of publication $\times$ Geographical location}

Table 4 (p. 334) reflects the yeatly totals for the various parts of Africa. Before 1949, South Africa contributed a relatively large percentage of the tatal number of publications; nevertheless, studies on South African populations numbered only half of those concerned with other sub-Saharan populations. The rapid expansion in the 1950 period was relatively greater for sub-Saharan Africa than

voL. $6, \mathrm{~N}^{\circ} 4$ 
for South Africa. In the nineteen-sixties, South Africa no longer showed an increase in number of publications, whereas the growth in number of studies concerned with sub-Saharan Africa and Africa as a whole was less than before, but still considerable.

\section{Language of publication $\times$ Year of publication, \& $\times$ Field of psycholog $y$}

Tables I and $s$ present, respectiwely, publication language against year of publication, and against field of psychology.

Over the period 1880-1949, English publications outnumbered French publications by a tatio of 3 to I (Table I). In the nineteen-fifties the number of

TABLE 4

NUMBER OF PUBLICATIONS PER PART OF AFRICA FOR VARIOUS PERIODS

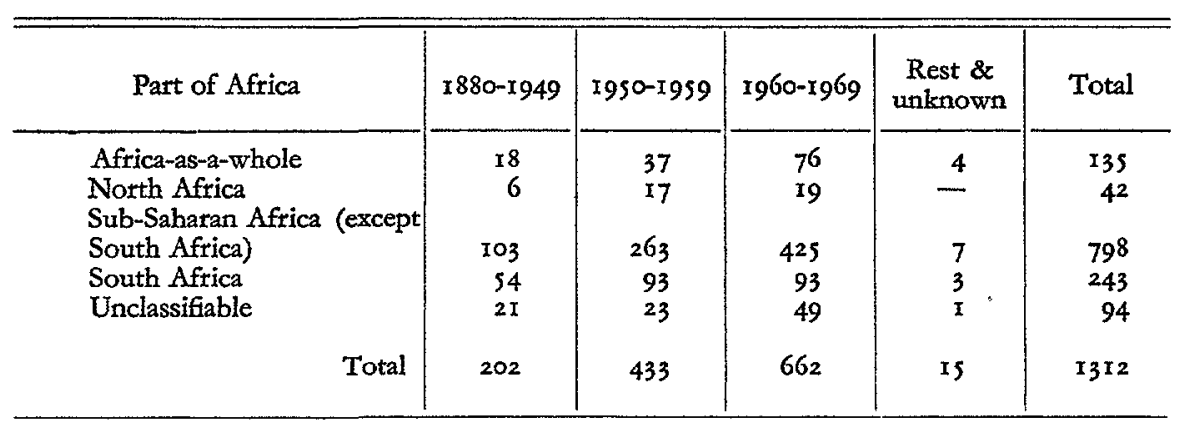

both English and French publications increased rapidly, but in the years since 1959, the English titles have shown an increase of $49 \%$, while French titles increased by only $3 \%$.

TABLE 5

NUMBER OF PUBLICATIONS PAR LANGUAGE IN DIFFERENT FIELDS OF PSYCHOLOGY

\begin{tabular}{l|c|c|c|c}
\hline \multicolumn{1}{c|}{ Field } & English & French & Other & Total \\
\cline { 2 - 4 } General & 31 & 36 & 3 & 70 \\
Methodology & 55 & 19 & 1 & 75 \\
Experimental & 18 & 4 & 3 & 25 \\
Physiological & 59 & 4 & 6 & 89 \\
Developmental & 74 & 44 & 5 & 123 \\
Social & 177 & 47 & 7 & 231 \\
Personality & 142 & 74 & 20 & 236 \\
Clinical & 116 & 79 & 12 & 207 \\
Educational & $7 x$ & 24 & 7 & 102 \\
Personnel & 89 & 50 & 5 & 154 \\
& & & 69 & 1312 \\
\hline
\end{tabular}

English and French publications differ in their distribution over subjects (Table 5). French titles were relatively overrepresented in general, clinical, and 
developmental psychology, while the great bulk of the studies in experimental, physiological, and social psychology were written in English. In particulat, experimental psychology seems confined to English publications.

\section{CONCLUSION}

Since 1880 , surprisingly large number of papers dealing with psychology in Africa have been published. The large and sudden increase in the number of publications in the fifties was followed by a more even development in the sixties.

As elsewhere, changes in the popularity of the various fields of psychology over decades seem to be a characteristic of psychology in Africa. However, there

* is reason to believe that psychology will become more oriented towards the needs and requirements of Africa, rather than towards the interests of incidental investigators. Furthermore, if the present trends continue, the English-speaking sub-Saharan countries (excepting South Africa) will become the main focus of psychology on the continent.

Finally, one can only hope that investigators will try to publish their work in journals more readily available to all workers in this field, rather than publishing in the diversity of journals noted.

\section{REFERENCES}

Ardit, R. Psychology in Latin America. American Psycbologist, 1968, 23, 567-574.

Hoorweg, J.C. \& Marars, H.C. Psychology in Africa. A bibliograpby. Leyden, The Netherlands : Afrika-Studiecentrum, 1969 .

Van Bergen, A. \& JaSPars, J.M.F. Social psychology in the Netherlands. Report SP 004-69. Psychological Institute, University of Leyden, The Netherlands : 1969. 